\title{
Growth Inhibition Screening Result
}

National Cancer Institute

\section{Source}

National Cancer Institute. Growth Inhibition Screening Result. NCI Thesaurus. Code C41121.

A Screening Result captures the results of the tens of thousands of compounds screened for their ability to inhibit the growth of selected yeast strains altered in DNA damage repair or cell cycle control. 